\title{
KAITAN KETINGGIAN LAPISAN BATAS ATMOSFER DENGAN KONDISI CUACA BERDASARKAN PROFIL ANGIN VERTIKAL BERBASIS PENGAMATAN RADISONDE, RADAR CUACA DAN KELUARAN MODEL WRF-ARW
}

\author{
Aries Kristianto $^{1^{*}}$, Annisa Puspa Rani ${ }^{2}$ \\ ${ }^{1}$ Program Studi Meteorologi, Sekolah Tinggi Meteorologi Klimatologi dan Geofisika, Jakarta \\ ${ }^{2}$ PMG Pelaksana Lanjutan, Stasiun Meteorologi Masamba \\ *Email : aries.kristianto@stmkg.ac.id
}

\begin{abstract}
ABSTRAK
Lapisan Batas Atmosfer (LBA) merupakan bagian dari atmosfer paling bawah dimana medan aliran sangat dipengaruhi langsung oleh interaksi dengan permukaan bumi dan sensitif terhadap berbagai kondisi di permukaan bumi selama skala waktu singkat. Ketinggian LBA dapat bervariasi secara signifikan terhadap waktu akibat dari beberapa faktor termasuk dinamika skala luas, perawanan, percampuran konvektif dan variasi diurnal dari radiasi matahari. Di Indonesia, kajian mengenai LBA masih terbatas, sehingga kajian ini dilakukan untuk mengetahui hubungan antara ketinggian LBA dengan kondisi cuaca menggunakan metode profil vertikal angin dari data pengamatan (radar dan radiosonde) dan simulasi model numerik WRF-ARW. Hasilnya menunjukkan antara LBA dan kondisi cuaca hanya memiliki tingkat korelasi yang sedang dengan bias yang cukup besar dengan hasil pengamatan, namun simulasi keluaran model WRF-ARW dapat menggambarkan dengan cukup baik profil ketinggian LBA pada kondisi cuaca yang berbeda. Kondisi cuaca dapat mempengaruhi ketinggian LBA, dimana saat kondisi cuaca cerah, ketinggian LBA lebih tinggi jika dibandingkan dengan kondisi cuaca berawan atau hujan.
\end{abstract}

Kata kunci: Lapisan Batas Atmosfer, Angin Vertikal, Radiosonde, Radar Cuaca, WRF-ARW

\section{ABSTRACT}

Atmospheric Boundary Layer $(A B L)$ is the lowest part of the atmosphere where the flow field is directly affected by interaction with earth's surface and sensitive to various condition at the surface. In a short period, $A B L$ height could varied significantly as a result of several factors, including large scale of atmospheric dynamics, cloudiness, convective mixing and diurnal variation of solar radiation. In Indonesia, studies related to $A B L$ is still limited, so in this study aims to know the relation between $A B L$ height and the weather condition using vertical wind profile from observation data (weather radar and radiosonde) and WRF-ARW model simulation. The result is though it has moderate correlation and high error towards the observation, WRF$A R W$ model simulation is able to determine the $A B L$ height profile in different weather condition. Weather conditions could be affected by the height of ABL. In fair weather conditions, the ABL height is higher than the $A B L$ height in cloudy or rainy weather conditions.

Keywords: Atmospheric Boundary Layer, Vertical Wind, Weather Radar,WRF-ARW

\section{PENDAHULUAN}

Ketinggian LBA dapat bervariasi secara signifikan terhadap waktu sebgai akibat dari beberapa faktor termasuk dinamika skala luas, perawanan, percampuran konvektif dan variasi diurnal dari radiasi matahari. Kajian mengenai LBA sangat penting dilakukan untuk berbagai proses atmosfer, termasuk pembentukan awan, aerosol, percampuran, tranportasi, transformasi dan percampuran bahan kimia (Zeng, 2004).
LBA sangat penting karena lapisan ini berpengaruh dalam prakiraan cuaca harian seperti kabut, embun, es dan suhu yang berkaitan erat dengan prediksi LBA dan bermanfaat dalam dispersi polutan, bahan kimia dan turbulensi di lapisan atmosfer dekat permukaan (Rao, 2004).Kajian mengenai LBA di wilayah benua maritim Indonesia masih terbatas, terutama identifikasi ketinggian dan 
variasi diurnal serta kaitan ketinggian LBA terhadap kondisi cuaca.

Penentuan ketinggian LBA dapat dilakukan dengan menggunakan radiosonde, radar cuaca dan model WRF-ARW berdasarkan penelitian yang dilakukan oleh Dewita (2015), Dewi (2012), Staudt (2006), Breuer dkk (2014) dan Bloch (2008). Pada studi ini dilakukan identifikasi ketinggian LBA menggunakan metode profil vertikal angin dari pengamatan radar cuaca dan radiosonde serta menggunakan simulasi model cuaca numerik skala meso WRF-ARW. Selanjutnya diidentifikasi ketinggian LBA, dan dinalisis variasi harian ketinggian LBA serta kaitannya dengan kondisi cuaca berdasarkan penelitian yang telah dilakukan oleh Yang dkk (2006).

\section{DATA DAN METODE}

Studi ini difokuskan hanya pada satu titik yaitu pada koordinat $6,126^{\circ}$ LS dan $106,654^{\circ}$ BT yaitu di Stasiun Meteorologi Soekarno-Hatta Cengkareng. Waktu penelitian dipilih berdasarkan data hasil pengamatan udara permukaan dan citra radar produk CMAX yaitu tanggal 05 Januari 2015 dengan kondisi berawan dan tidak hujan, diasumsikan sebagai kondisi cuaca cerah. Tanggal 04 Januari 2015 dengan kasus hujan dan tutupan awan jenis stratiform. Tanggal 22 Januari 2015, dengan kasus hujan dan tutupan awan jenis cumuliform (awan konvektif).

Dalam penelitian ini, pengolahan data dilakukan dengan menggunakan Software RAOB (the Rawinsonde Observation Program) versi 5.8 untuk mengolah data hasil yang digunakan untuk mengolah data FNL, sistem operasi linux ubuntu 16 digunakan sebagai sistem operasi dalam pengolahan data menggunakan WRF-ARW, aplikasi EDGE (Enterprise Doppler Graphics Environment) untuk mengolah raw data dari radar cuaca EEC, serta model numerik WRF-ARW.

Data yang digunakan dalam penelitian ini antara lain data pengamatan udara permukaan,

data pengamatan udara atas, data pengamatan radar cuaca dan data FNL. Data pengamatan udara permukaan digunakan untuk mengidentifikasi kasus berdasarkan kondisi cuacanya. Kasus dipilih berdasarkan kondisi cuaca signifikan yang terjadi, dalam hal ini hujan dan tidak hujan. Selain itu, kasus juga dipilih berdasarkan kondisi perawanannya, dalam hal ini jenis awan stratiform dan cumuliform (awan konvektif).

Data pengamatan udara atas diolah menggunakan software RAOB. Parameter yang diolah adalah kecepatan angin horizontal per lapisan, seperti ditunjukkan oleh Gambar 1.

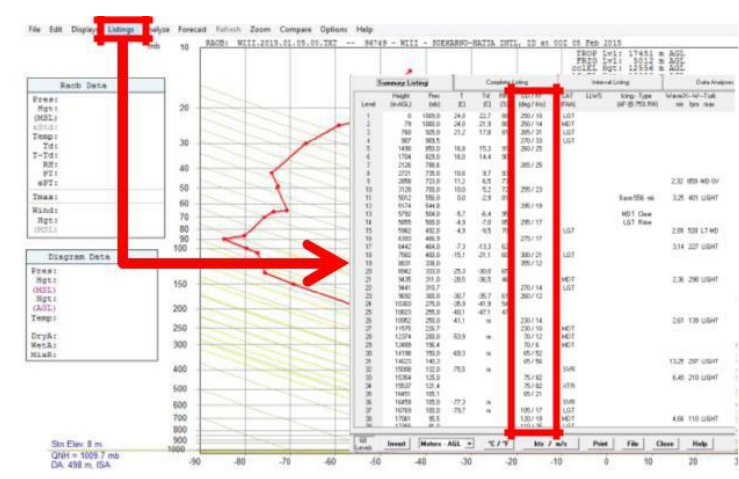

Gambar 1. Contoh pengolahan data angin RAOB

Profil angin hasil dari pengamatan udara atas, selanjutnya secara visual, ditentukan ketinggian LBA berdasarkan adanya geser angin maksimum.

Data radar berupa produk CMAX (Column Maximum) dan VVP (Volume Velocity Processing) diolah menggunakan software EDGE. CMAX merupakan produk radar untuk menampilkan nilai reflektivitas maksimum dalam satu kolom volume scan yang selanjutnya diproyeksikan ke dalam bidang horizontal. Konfigurasi produk CMAX

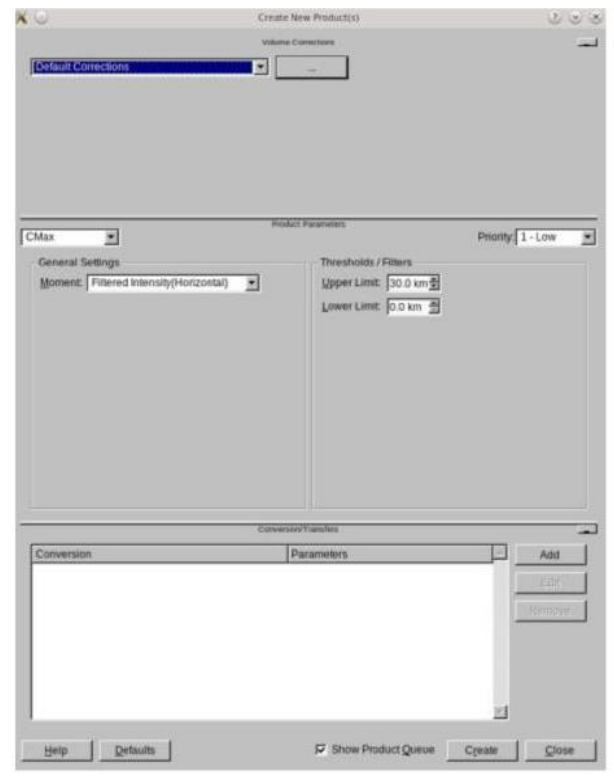

Gambar 2. Konfigurasi produk CMAX 
ditunjukkan oleh Gambar 2. Produk CMAX digunakan untuk mengidentifikasi adanya tutupan awan di lokasi penelitian berdasarkan nilai reflektivitasnya.

VVP merupakan produk radar untuk menampilkan beberapa parameter udara secara vertikal seperti arah dan kecepatan angin horizontal, kecepatan angin 3 dimensi ( $\mathrm{u}, \mathrm{v}$ dan w), divergensi, deformation, shear, vertical divergence, horizontal divergence, $3 D$ divergence dan vertical shear. Produk VVP digunakan untuk menentukan profil vertikal angin yang berpusat di atas radar site. Beberapa parameter berasal dari rata-rata radial velocity dari suatu polar volume (Waldteufel dan Corbin, 1979). Konfigurasi produk VVP ditunjukkan oleh Gambar 3.

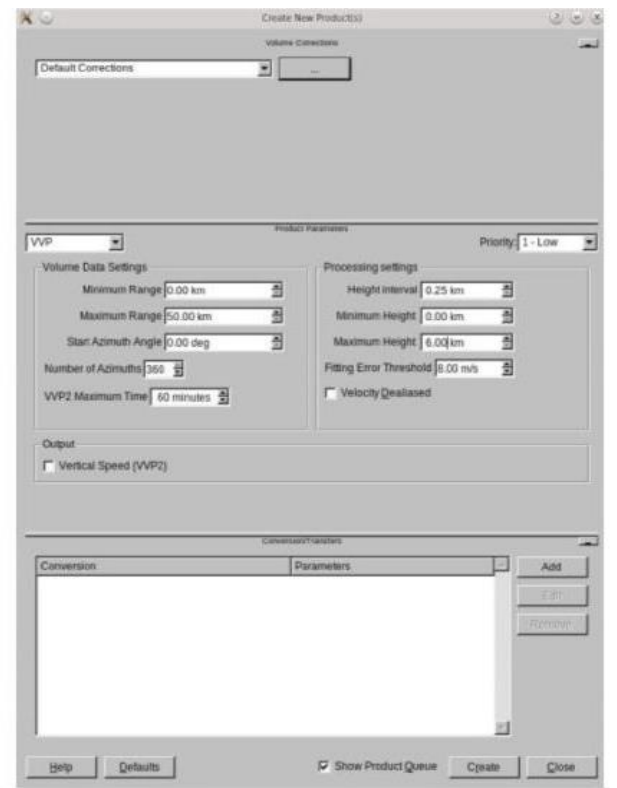

Gambar 4. Profil vertikal suhu (T), suhu potensial $(\theta)$, Kelembapan spesifik (q), dan kecepatan angin (V) di troposfer bagian bawah. Atmosfer bebas (FA), entrainment zone (EZ), Lapisan Percampuran (ML), Lapisan Permukaan (SL), Capping Inversion (CI), lapisan residual (RL), LBA Stabil (SBL), ketinggian lapisan CI (zi) sebagai puncak dari LBA (BL), dan kecepatan angin geostropik $(\mathrm{Vg})$ pada siang hari (a) dan malam hari (b) yang diidentifikasi dalam penelitian ini untuk ketinggian LBA ditandai oleh kotak merah (Wallace dan Hobbs, 2006)
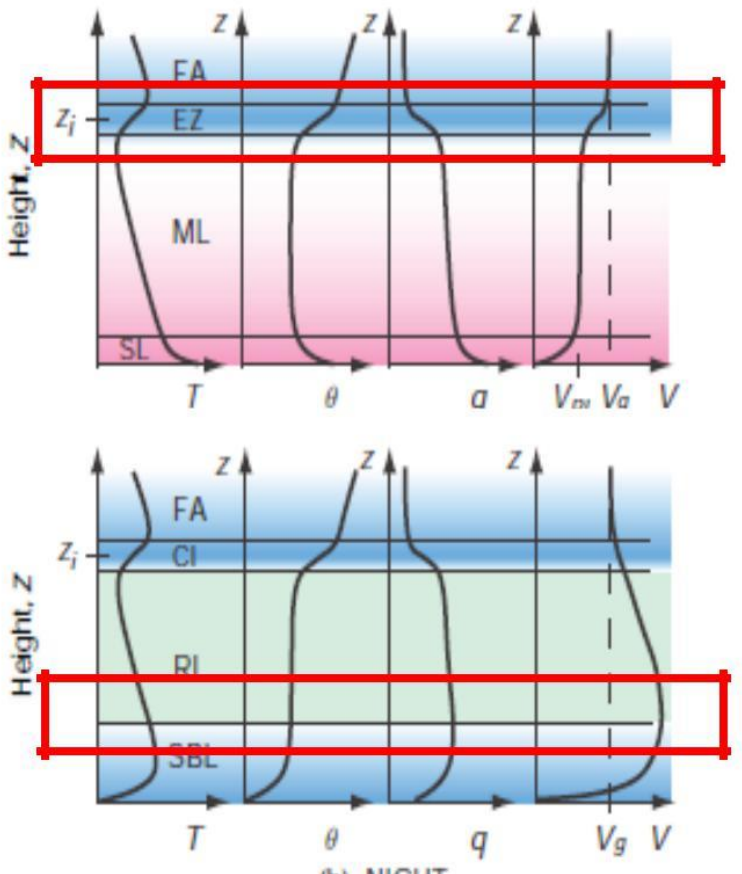

(b) NIGHT

Gambar 3. Konfigurasi produk VVP

Produk VVP digunakan untuk melihat profil vertikal angin dan untuk mengidentifikasi ketinggian LBA yang ditandai oleh adanya geser angin maksimum. Data kecepatan angin horizontal per lapisan dari pengamatan radar (produk VVP) dan radiosonde dianalisis untuk membuat profil vertikal angin. Ketinggian LBA ditentukan dengan melihat profil vertikal angin (Gambar 4), dimana puncak ketinggian LBA pada siang hari ditandai oleh adanya peningkatan kecepatan angin akibat tidak terjadi lagi turbulensi (angin geostropik). Pada malam hari, melemahnya turbulensi akibat lapisan stabil menyebabkan berkurangnya gesekan dan mengakibatkan terjadinya kecepatan angin maksimum pada lapisan bawah.

Data FNL dari NCEP dari http://rda.ucar.edu/ selanjutnya dilakukan running model WRFARW dengan pengaturan domain induk pada koordinat $6,125^{\circ}$ LS dan $165,65^{\circ}$ BT . Selanjutnya dilakukan downscalling dan nesting hingga 3 domain seperti pada Tabel 1 . 
Tabel 1. Tabel konfigurasi domain WRF-ARW

\begin{tabular}{|c|c|c|c|}
\hline Konfigurasi & \multicolumn{3}{|c|}{ Domain } \\
\hline Resolusi Model & $30 \mathrm{~km}$ & $10 \mathrm{~km}$ & $3,3 \mathrm{~km}$ \\
\hline $\begin{array}{c}\text { Resolusi Data Geog } \\
\text { e_we (dimensi barat- } \\
\text { timur) }\end{array}$ & $10 \mathrm{~m}$ & $5 \mathrm{~m}$ & $30 \mathrm{~s}$ \\
\hline $\begin{array}{c}\text { e_sn (dimens1 utara - } \\
\text { selatan) }\end{array}$ & 100 & 88 & 76 \\
\hline e_vert (dimensi vertikal) & 30 & 30 & 30 \\
\hline History Interval & 180 & 180 & 60 \\
\hline Time Step & & 180 & \\
\hline Run Hours & & 30 & \\
\hline
\end{tabular}

Skema parameterisasi yang digunakan, menggunakan skema parameterisasi default. Pada setiap domain, dipakai skema yang sama. Skema parameterisasi default tersebut antara lain seperti pada Tabel 2.

Tabel 2. Skema parameterisasi default WRF-ARW

\begin{tabular}{|l|l|l|}
\hline Skema Parameterisasi & Angka & Pilihan Skema \\
\hline Mikrofisik & 3 & WSM-3 \\
\hline Kumulus & 1 & Kain-Fritsch \\
\hline Radiasi Gelombang Pendek & 1 & Dudhia \\
\hline Radiasi Gelombang Panjang & 1 & RRTM \\
\hline BL (Planetary Boundary Layer) & 1 & YSU \\
\hline
\end{tabular}

Verifikasi digunakan untuk melihat hubungan keterkaitan dan akurasi antara simulasi model dan hasil observasi. Dalam hal ini karena tidak ada pengamatan langsung untuk parameter ketinggian LBA, hasil dari pengukuran radar cuaca dan pengamatan udara atas dijadikan sebagai pembanding utama karena dianggap dapat mewakili kondisi sebenarnya. Oleh karena itu, verifikasi dalam penelitian ini dilakukan dengan membandingkan hasil model WRF-ARW dengan hasil pengukuran radar cuaca dan hasil pengamatan udara atas. Diagram alir penelitian ditunjukkan oleh Gambar 5.

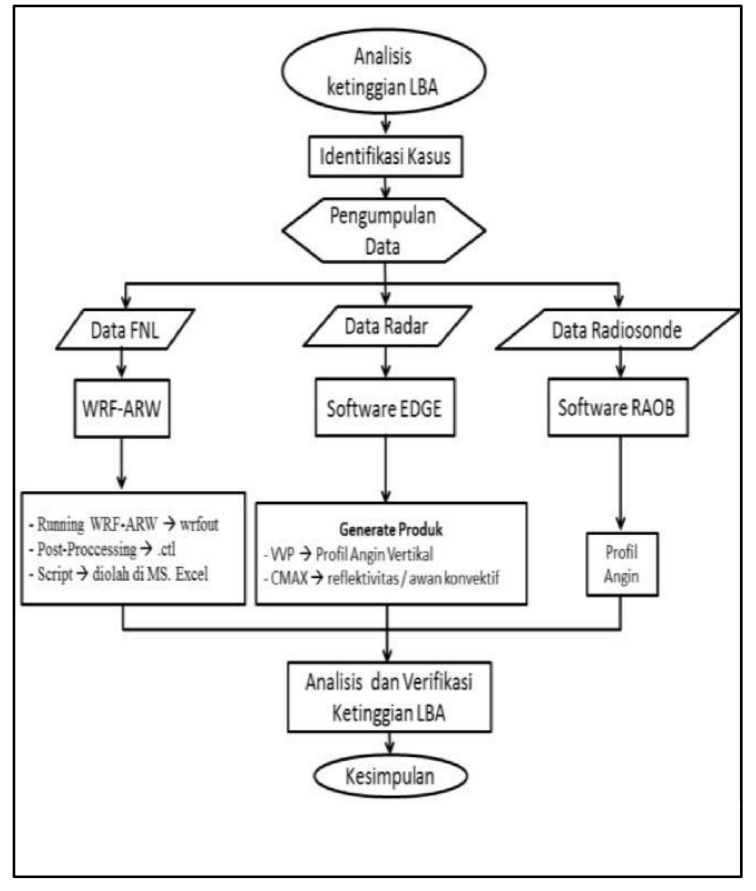

Gambar 5. Diagram alir penelitian

\section{HASIL DAN PEMBAHASAN}

\subsection{Identifikasi Ketinggian LBA}

Penentuan ketinggian LBA dengan menggunakan profil vertikal angin (radar cuaca dan radiosonde) dan simulasi model WRFARW diperoleh hasil seperti pada Gambar 6 . Ketinggian LBA bervariasi terhadap waktu dan kondisi cuaca yang terjadi.

Ketinggian LBA tanggal 05 Januari 2015 tidak dapat diidentifikasi oleh profil vertikal angina radar cuaca karena pola dari profil angin yang tidak beraturan. Sedangkan dari profil vertical angin pengamatan radiosonde pada pukul 07.00 WIB ketinggian LBA sekitar 419,5 meter, pukul 19.00 WIB ketinggian LBA sekitar 405,5 meter dan pada pukul 07.00 WIB di hari berikutnya sekitar 421 meter. Berdasarkan hasil simulasi model WRF-ARW diperoleh ketinggian LBA maksimum yaitu pada siang hari pukul 13.00 WIB yaitu 1361,3 meter sedangkan ketinggian LBA minimum pada pagi hari pukul 07.00 WIB yaitu 108,8 meter. Ketinggian LBA tanggal 04 Januari 2015 pada pagi hari (07.00-12.00 WIB) Ketinggian LBA berkisar 200-500 meter, pada siang hari (13.00-15.00 WIB ketinggian LBA berkisar 500 - 875 meter dan pada malam hari turun hingga ketinggian sekitar 200 meter. Sedangkan dari profil vertikal angin pengamatan radiosonde pada pukul 07.00 WIB 
ketinggian LBA sekitar 423 meter, pukul 19.00 WIB ketinggian sekitar 412 meter dan pada pukul 07.00 WIB di hari berikutnya sekitar 419,5 meter. Hasil keluaran simulasi model WRF-ARW diperoleh ketinggian LBA maksimum yaitu pada siang hari pukul 12.00 WIB yaitu 1337,5 meter, sedangkan ketinggian LBA minimum pada pagi hari pukul 07.00 WIB yaitu 161,3 meter. Ketinggian LBA tanggal 22 Januari 2015 pada pagi hari (10.00-12.00 WIB) Ketinggian LBA berkisar sekitar 200 meter, pada siang hari (13.00-15.00 WIB) ketinggian LBA berkisar 500 meter dan pada malam hari turun hingga ketinggian sekitar 200 meter. Sedangkan dari profil vertikal angin pengamatan radiosonde pada pukul 07.00 WIB ketinggian LBA sekitar 456 meter, pukul 19.00 WIB ketinggian LBA sekitar 447 meter dan pada pukul 07.00 WIB di hari berikutnya sekitar 436 meter.

Hasil simulasi model WRF-ARW menunjukkan ketinggian LBA maksimum yaitu pada siang hari pukul 12.00 WIB yaitu 951,1 meter sedangkan ketinggian LBA minimum pada pagi hari pukul 07.00 WIB yaitu 35,7 meter.

\subsection{Ketinggian LBA pada Kondisi Cuaca yang Berbeda}

Ketinggian LBA dapat bervariasi secara signifikan terhadap waktu. Hal ini dapat disebabkan oleh siklus harian penyinaran matahari. Selain itu, kondisi cuaca yang terjadi juga dapat mempengaruhi pertumbuhan dan perkembangan LBA. Pada Gambar 7. menunjukkan ketinggian LBA dari simulasi model WRF-ARW pada beberapa hari dengan kondisi cuaca yang berbeda. Tanggal 05 Januari 2015 mewakili kondisi cuaca cerah, tanggal 04 Januari 2015 mewakili kondisi cuaca hujan dengan tutupan awan jenis stratiform sedangkan tanggal 22 Januari 2015 mewakili kondisi cuaca hujan dengan tutupan awan cumuliform (awan convektif).

Pada kondisi cuaca yang berbeda, ketinggian LBA juga bervariasi. Seperti ditunjukkan oleh Gambar 8., pada kondisi cuaca hujan dengan tutupan awan cumuliform (awan konvektif) ketinggian LBA cenderung lebih rendah jika dibandingkan dengan kondisi cuaca lainnya sedangkan pada kondisi cuaca cerah, ketinggian LBA cenderung lebih tinggi dibandingkan kondisi cuaca lainnya.

\subsection{Verifikasi model WRF-ARW dengan pengamatan radar cuaca dan radiosonde}

Berdasarkan hasil identifikasi ketinggian LBA dengan menggunakan profil angin (radar dan radiosonde) dan simulasi model WRF-ARW diperoleh hasil ketinggian LBA (Tabel 3.). Hasil verifikasi berupa hubungan keterkaitan dan nilai bias antara model (WRF-ARW) dengan pengamatan (radar dan radiosonde) menunjukkan korelasi model-radar sebesar 0,23 merupakan nilai korelasi lemah yang berbanding lurus dan korelasi modelradiosonde sebesar -0,52 menunjukkan nilai korelasi sedang yang berbanding terbalik. Nilai bias dihitung menggunakan RMSE, diperoleh bias model-radar 434,6 meter dan bias modelradiosonde 291,2 meter. Dari kedua hasil perhitungan diperoleh hubungan terbaik dan error paling kecil menggunakan pengamatan radiosonde, akan tetapi pelepasan rasiosonde yang hanya dilakukan 2 kali sehari tidak cukup baik menggambarkan profil ketinggian LBA dalam sehari (variasi harian).

Ketinggian LBA bervariasi terhadap waktu dan kondisi cuaca yang terjadi. Ketinggian LBA maksimum (puncak) terjadi pada siang hari dimana penyinaran matahari juga maksimum. Hal ini disebabkan oleh tingginya suhu atau panas sensibel pada siang hari dimana panas sensibel merupakan energi dominan untuk mempertahankan pertumbuhan LBA. Ketinggian LBA minimum (lembah) terjadi pada

malam hari atau pagi hari (sebelum terbitnya matahari) disebabkan oleh pendinginan radiatif permukaan bumi.

Namun, ada faktor lain yang juga mempengaruhi ketinggian LBA yaitu kondisi cuaca yang terjadi. Dimana ketika ada tutupan awan atau hujan, ketinggian LBA dapat turun hingga beberapa ratus meter. Hal ini dikarenakan tutupan awan dan hujan tersebut berperan dalam menurunkan suhu permukaan bumi sehingga energi dominan yang mendukung pertumbuhan LBA berkurang. Ketika cuaca cerah, permukaan bumi menerima radiasi matahahari secara langsung sehingga panas sensibel di permukaan bertambah. Hal ini yang menyebabkan pada kondisi cuaca cerah, ketinggian LBA lebih tinggi jika dibandingkan dengan kondisi cuaca berawan atau hujan. 


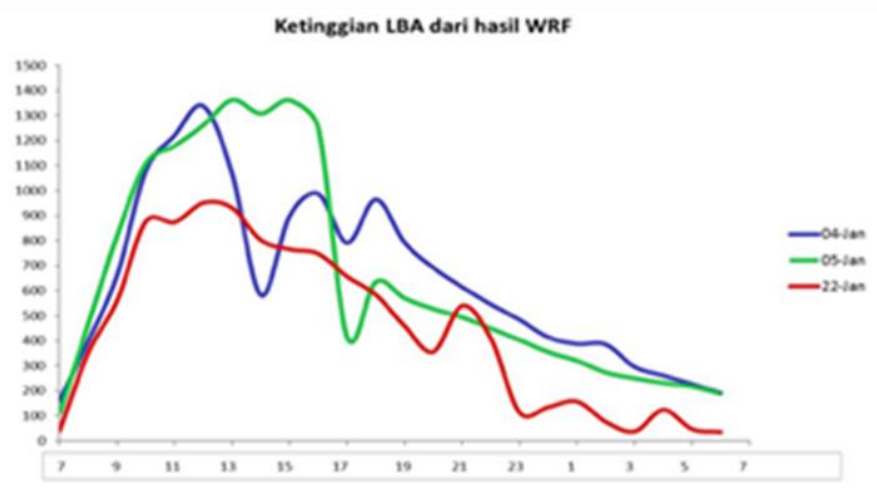

Gambar 6. Penentuan ketinggian LBA (meter) dari profil angin radar cuaca (kotak- hijau), profil angin radiosonde (segitiga - merah) dan simulasi model WRF-ARW (garis - biru) pada tanggal (kiri) 05 Januari 2015 (kondisi cuaca cerah), (tengah) 04 Januari 2015 (kondisi cuaca hujan dengan tutupan awan jenis stratiform) dan (kanan) 22 Januari 2015 (kondisi cuaca hujan dengan tutupan awan jenis cumuliform).

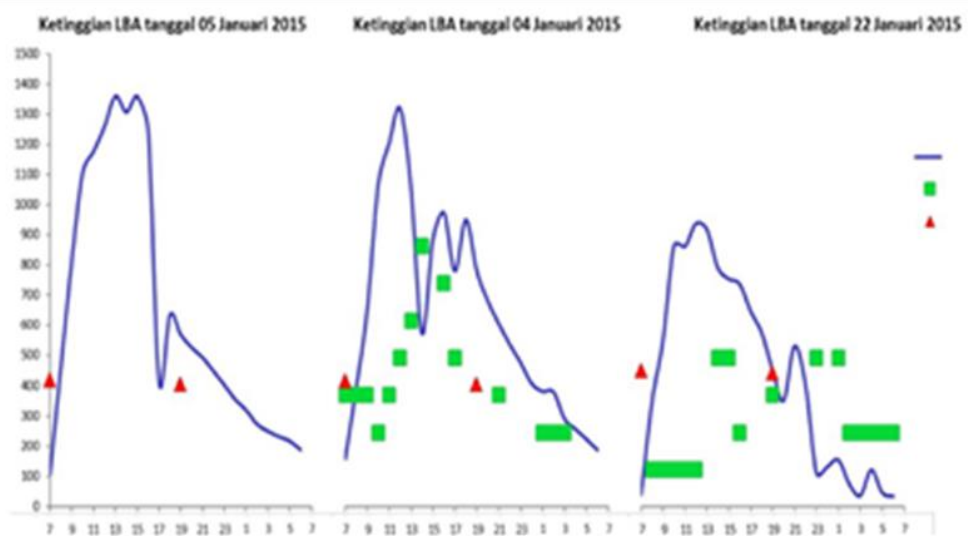

Gambar 7. Ketinggian LBA (meter) hasil simulasi model WRF-ARW tanggal 04 (hijau), 05 (biru) dan 22 (merah) Januari 2015.

Tabel 3. Hasil identifikasi ketinggian LBA dengan menggunakan profil angin (radar dan radiosonde) dan hasil keluaran simulasi model WRF-ARW

\begin{tabular}{|c|c|c|c|c|c|c|c|c|c|c|c|}
\hline \multirow[b]{2}{*}{ Waktu (WIB) } & \multicolumn{3}{|c|}{ Radar } & \multirow[b]{2}{*}{ Waktu (WIB) } & \multicolumn{3}{|c|}{ Radiosonde } & \multirow[b]{2}{*}{ Waktu (WIB) } & \multicolumn{3}{|c|}{ WRF-ARW } \\
\hline & 04 Januari 2015 & 05 Januari 2015 & 22 Januari 2015 & & 04 Januari 2015 & 05 Januari 2015 & 22 Januari 2015 & & 04 Januari 2015 & 05 Januari 2015 & 22 Januari 2015 \\
\hline 7 & 375 & & & 7 & 423 & 419 & 456 & 7 & 161,307 & 108,8 & 41,399 \\
\hline 8 & 375 & & 125 & 8 & & & & 8 & 399,415 & 467,6 & 353,284 \\
\hline 9 & 375 & & 125 & 9 & & & & 9 & 661,306 & 818,7 & 560,633 \\
\hline 10 & 250 & & 125 & 10 & & & & 10 & 1079,601 & 1108,9 & 877,724 \\
\hline 11 & 375 & & 125 & 11 & & & & 11 & 1220,757 & 1178,4 & 873,664 \\
\hline 12 & 750 & & 125 & 12 & & & & 12 & 1337,552 & 1261,4 & 951,138 \\
\hline 13 & 625 & & & 13 & & & & 13 & 1068,107 & 1361,3 & 931,143 \\
\hline 14 & 625 & & 500 & 14 & & & & 14 & 582,174 & 1308,2 & 802,492 \\
\hline 15 & & & 500 & 15 & & & & 15 & 899,042 & 1360,5 & 765,478 \\
\hline 16 & 750 & & 250 & 16 & & & & 16 & 987,596 & 1249,9 & 747,43 \\
\hline 17 & 500 & & & 17 & & & & 17 & 791,536 & 415,9 & 656,668 \\
\hline 18 & & & & 18 & & & & 18 & 964,404 & 635,4 & 583,992 \\
\hline 19 & 500 & & 375 & 19 & 412 & 405 & 447 & 19 & 792,412 & 570,1 & 458,794 \\
\hline 20 & & & & 20 & & & & 20 & 691,882 & 527,3 & 356,365 \\
\hline 21 & 375 & & & 21 & & & & 21 & 614,947 & 494,1 & 540,222 \\
\hline 22 & & & & 22 & & & & 22 & 545,766 & 449,5 & 409,911 \\
\hline 23 & & & 500 & 23 & & & & 23 & 484,001 & 403,3 & 112,948 \\
\hline 0 & & & & 0 & & & & 0 & 414,186 & 355 & 135,392 \\
\hline 1 & 250 & & 500 & 1 & & & & 1 & 387,953 & 320 & 157,408 \\
\hline 2 & 250 & & 250 & 2 & & & & 2 & 385,577 & 273,3 & 76,244 \\
\hline 3 & 250 & & 250 & 3 & & & & 3 & 295,645 & 250,1 & 38,324 \\
\hline 4 & & & 250 & 4 & & & & 4 & 261,279 & 232 & 124,279 \\
\hline 5 & & & 250 & 5 & & & & 5 & 227,226 & 217,3 & 47,397 \\
\hline 6 & & & 250 & 6 & & & & 6 & 191,268 & 188,1 & 35,743 \\
\hline
\end{tabular}




\section{KESIMPULAN}

Berdasarkan hasil analisis dan pembahasan dapat disimpulkan bahwa ketinggian LBA dapat diidentifikasi menggunakan profil vertikal angin menggunakan radar dan radiosonde, selain itu juga dapat diidentifikasi menggunakan simulasi model WRF-ARW. Walaupun memiliki korelasi sedang dan

Pemanfaatan model numerik baik dari sisi parameterisasi atau resolusi tinggi sangat disarankan karena fenomena LBA ini merupakan fenomena skala lokal. Pengamatan ketinggian LBA juga sangat bermanfaat dalam hal menentukan tinggi dasar awan. Namun, diperlukan data dalam jangka waktu yang lebih panjang (klimatologi) sehingga dapat mengetahui seberapa dekat hubungan antara ketinggian LBA dengan tinggi dasar awan.

Profil vertikal angin menggunakan radar cuaca memiliki pola yang tidak teratur, variasi kecepatan angin kadang terlalu besar terhadap ketinggian. Dalam beberapa kasus, profil vertikal angin terputus-putus sehingga sulit untuk menentukan ketinggian LBA. Sedangkan profil vertikal angin menggunakan pengamatan radiosonde baik karena melakukan pengamatan angin secara langsung menggunakan pelepasan radiosonde, namun karena pengamatan hanya dilakukan 2 kali dalam sehari sehingga tidak dapat merepresentasikan variasi diurnal dari ketinggian LBA.

\section{DAFTAR PUSTAKA}

Bloch, L. A. 2008. Evaluation of Daytime Boundary Layer Heights From a Mesoscale Model Using Profilers/Rass Measurements, Tesis, Naval Postgraduate School Monterey: California.

Breuer, H., Acs, F., Horvath, A., Nemeth, P., dan Rajkai, K. 2014. Diurnal Course Analysis of the WRF-Simulated and Observation - Based Planetary Boundary Layer Height, Advances in Science and Research, Volume 11, 2014, pp.83-88, http://www.adv-scires.net/11/83/2014/asr-11-83- memiliki nilai bias yang cukup besar dengan hasil pengamatan, keluaran model WRF-ARW telah menggambarkan dengan cukup baik profil ketinggian LBA pada kondisi cuaca yang berbeda. Ketinggian LBA pada cuaca cerah akan lebih tinggi jika dibandingkan dengan ketinggian LBA pada kondisi cuaca berawan dan hujan.

2014.pdf, diakses pada tanggal 21 Nov 2015.

Dewi, S. 2012. Identifikasi Ketebalan Lapisan Batas Atmosfer Menggunakan Profil Angin Radar Doppler di Daerah Tangerang dan Sekitarnya, http://www.meteo.itb.ac.id/wpcontent/uploads/2013/05/12808028sec.pdf, diakses pada tanggal 25 November 2015.

Dewita, A. 2015. Identifikasi Tebal Lapisan Batas Atmosfer Menggunakan Data Velocity dan Spectral Width Radar serta Parameter Turbulensi dari WRFARW di Daerah Jakarta dan Sekitarnya, Jurnal Meteorologi Klimatologi dan Geofisika, Vol. 2 No. 2 Juni 2015, Halaman 156-165.

Rao, K. S. 2005. Uncertainty Analysis in Atmospheric Dispersion Modeling,

Staudt, K. 2006. Pure Appl. Geophys., 162, 1894-1917. Determination of the Atmospheric Boundary Layer Height in Complex Terrain During SALSA 2005, Tesis, Department of Micrometeorology University of Bayreuth: Bayreuth.

Stull, R. B. 1988. An Introduction to Boundary Layer Meteorology. Kluwer Academic Publisher, The Netherlands.

UCAR. 2015. Introduction to Tropical Meteorology 2nd Edition, [daring], http://www.meted.ucar.edu/tropical/te xtbook_2nd_edition/print_6.htm\#pag $e$ _o.0.0, diakses pada $\overline{4}$ November 2015

Waldteufel, P., dan Corbin, H. 1979. On the analysis of single Doppler radar data. J. Appl. Meteor., 18, 532.542. 
Wallace, J. M., dan Hobbs, P. V. 2006. Atmospheric Science 2nd Edition, USA: Elsevier Academic Press.

Wardoyo, E. 2013. Materi Radar Produk EEC. Training Radar Cuaca, Badan Meteorologi Klimatologi dan Geofisika, Jakarta.

Wardoyo, E. 2015. Radar Meteorologi. Draft Buku Meteo Radar. Badan Meteorologi Klimatologi dan Geofisika, Jakarta.

Wilks, D.S. 2006. Statistical Methods in the Atmospheric Science, $2^{\text {nd }}$ edition. International Geophysics Series, Vol. 91, Elsevier, Inc.

WMO. 2000. Guidelines on Performance Assessment of Public Weather Service, WMO/TD No. 1023, Geneva, Switzerland.

Yang, K., Koike T., Fujii H., Tamura T., Xu X., Bian L., dan Zhou M. 2004. The Daytime Evolution of the Atmospheric Boundary Layer and Convection over the Tibetan Plateau: Observations and Simulations,
Zeng, X., Brunke M. A., Zhou M., Fairall C., Bond N. A., dan Lenschow D. H. 2004. Marine Atmospheric Boundary Layer Height over the Eastern Pacific: Data Analysis and Model Evaluation, Journal of Climate. Vol. 17, no. 21, 4159-4170. November 2004,

http://journals.ametsoc.org/doi/pdf/10 
